\section{Rencana Mutu Kontrak Pembangunan Saluran Sekunder Dan Lining Saluran Pada Saluran Primer Daerah Irigasi Amandit Di Kabupaten Hulu Sungai \\ Selatan}

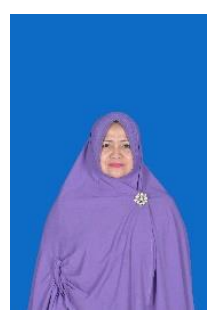

\section{Norhayati.}

Lahir di Banjarmasin, pada tanggal 4 Maret 1964 anak ke empat dari delapan bersaudara dari ayah bernama Muhammad Ramlan dan ibu bernama Nursinah adalah seorang direktur perusahaan lokal dalam bidang konstruksi, pendidikan terakhir adalah sarjana strata 1 program studi Teknik Sipil Universitas Lambung Mangkurat.buletinppi@ulm.ac.id

\section{Pendahuluan}

Jasa Konstruksi di bidang pengelolaan sumber daya air di Indonesia terus berkembang hal ini disebabkan terhadap pertambahan jumlah penduduk yang mengakibatkan keperluan akan pangan meningkat sehingga kebutuhan masyarakat akan hasil pertanian akan terus meningkat. Pengelolaan sumber daya air akan produksi pertanian menuntut lebih baik dalam pengelolaan jaringan irigasi yang lebih komplek untuk meningkatkan produksi pertanian. Hal ini dipengaruhi oleh kapasitas debit aliran air dan dimensi saluran untuk menyuplai air ke sawah selama bercocok tanam dalam setahun.

Sesuai dengan kebijakan mutu oleh Departemen Pekerjaan Umum nomor : 04/PRT/M/2009 tentang sistem manajemen mutu (SMM). Peraturan ini untuk memberikan panduan melaksanakan manajemen organisasi yang mengarah kepada perencanaan, penerapan, pemeliharaan, dan peningkatan bagi pencapaian kinerja yang berlandaskan sistem manajemen mutu yang terdokumentasi dan terintegrasi sesuai dengan kebijakan mutu yang berkelanjutan.

Tidak sempurnanya hasil akhir pekerjaan atau terjadinya gagal fungsi bangunan akan berdampak pada laporan-laporan masyarakat yang akhirnya akan menuju keranah hukum. Sering kali penyimpangan tersebut terjadi pada prosedur pekerjaan dimana akan mengakibatkan pembengkakan biaya dan waktu namun hal ini sering sekali diabaikan oleh penyedia jasa dan pengguna jasa.

Pada pekerjaan pembangunan saluran sekunder dan lining saluran pada saluran primer daerah irigasi Amandit di kabupaten Hulu Sungai Selatan menggunakan pengendalian mutu yang berpedoman
Pada pembangunan saluran sekunder dan lining saluran pada saluran primer daerah irigasi amandit di kabupaten hulu sungai selatan menggunakan pengendalian mutu yang berpedoman pada peraturan menteri nomor : 04/PRT/M/2009 tentang sistem manajemen mutu (SMM) yang dituangkan dalam dokumen rencana mutu kontrak (RMK). pengendalian mutu dihitung berdasarkan seberapa besar kepatuhan pelaksaanaan pekerjaan terhadap produk penjaminan mutu antara lain penyedia jasa terhadap dokumen Rencana Mutu Kontrak (RMK) dan kepatuhan pengawas lapangan terhadap spesifikasi teknis, gambar teknis, dan dokumen administrasi terkait mutu. Pada proyek ini untuk pekerjaan tanah dan pekerjaan beton yang merupakan item mayor dalam pelaksanaan proyek sudah sesuai dengan pengendalian mutu hal ini terlihat dari prosedur yang dikerjakan sesuai dengan spesifikasi teknis dan gambar kerja pada peraturan menteri nomor : 04/PRT/M/2009 tentang sistem manajemen mutu (SMM) yang dituangkan dalam dokumen rencana mutu kontrak (RMK). Dokumen rencana mutu kontrak adalah suatu panduan pengendalian mutu sesuai dengan spesifikasi teknis agar meminimalkan terjadinya kegagalan konstruksi.

\section{Hasil Kerja}

Irigasi adalah usaha untuk memperoleh air yang menggunakan bangunan dan saluran buatan untuk keperluan penunjang produksi pertanian (Mawardi ; 2007). Tujuan utama irigasi adalah mewujudkan kemanfaatan air yang menyeluruh, terpadu, dan berwawasan lingkungan, serta meningkatkan kesejahteraan masyarakat, khususnya petani (Peraturan Pemerintah : 2001). Tersedianya air irigasi memberikan manfaat dan kegunaan lain, seperti:

1. Mempermudah pengolahan lahan pertanian.

2. Memberantas tumbuhan pengganggu.

3. Mengatur suhu tanah dan tanaman.

4. Memperbaiki kesuburan tanah.

5. Membantu proses penyuburan tanah.

Dalam memenuhi kebutuhan air irigasi harus menerapkan managemen yang didukung oleh teknologi dan perangkat hukum yang baik. Pemanfaatan sumber daya air diatur sedemikian rupa agar sesuai dengan keperluan tanaman. Pengelolaan yang baik berarti bangunan irigasi serta fasilitasnya perlu dikelola secara tertib dan teratur di bawah pengawasan dan pertanggungjawaban suatu instansi atau organisasi Perkumpulan Pertani Pemakai Air (P3A) (Peraturan pemerintah ; 2001). 
Ditinjau dari sudut pengelolaannya, sistem irigasi dibagi menjadi:

1. Sistem irigasi non teknis yaitu irigasi yang dibangun oleh masyarakat dan pengelolaan seluruh bangunan irigasi dilakukakan sepenuhnya oleh masyarakat setempat.

2. Sistem irigasi teknis yaitu suatu sistem yang dibangun oleh pemerintah dan pengelolaan jaringan utama yang terdiri dari bendung, saluran primer, saluran sekunder dan seluruh bangunan dilakukan oleh pemerintah, dalam hal ini DPU atau Pemerintah Daerah setempat. Sedangkan jaringan tersier dikelola oleh masyarakat.

Pertambahan pendudukan dan berkembangnya Provinsi Kalimantan Selatan khususnya di Kabupaten Hulu Sungai Selatan menyebabkan diperlukan peningkatan produksi pertanian dan jaminan ketahanan pangan seperti daerah lain di Provinsi Kalimantan Selatan. Mempertimbangkan kondisi tersebut dan prediksi beberapa tahun ke depan, maka dilakukan upaya pengembangan jaringan irigasi amandit.

Sumber air Daerah Irigasi Amandit adalah sungai Amandit yang dibendung di desa Malutu Kecamatan Padang Batung. Direncanaka luas areal yang dapat diairi mencapai $5.472 \mathrm{Ha}$ yang terbagi dalam wilayah layanan sebelah kiri dan kanan sungai Amandit yang tersebar di Kecamatan Padang Batung Kandangan, Sungai Raya, Simpur dan Angkinang.

Perencanaan Daerah Irigasi Amandit ini telah dilakukan sejak tahun 1984 dengan melakukan kegiatan Studi Survey, Investigasi dan Desain. Yang dilanjutkan dengan kegiatan Soil dan Geotechnic pada tahun 1985, dan pada tahun 2000 dilaksanakan Studi AMDAL oleh Lembaga Penelitian UNLAM, dan Kegiatan Review Design Main Canal Amandit Irrigation System oleh Konsultan PTSL-II pada tahun 2003. Baru pada tahun 2005 sampai 2007 Pelaksanaan Pekerjaan Bangunan Utama (bendung) dan Jaringan Utama (saluran primer) selesai dikerjakan. Pada tahun 2009 dilaksanakan pembangunan saluran sekunder dan lining saluran primer daerah irigasi amandit. Hal ini dilakukan pemerintah agar pada daerah irigasi amandit terkelola menjadi sistem irigasi teknis.

Mutu didefinisikan sebagai gambaran atau karek teristik menyeluruh barang/jasa yang menunjukkan kemampuannya dalam pemenuhan persyaratan yang ditentukan atau yang tersirat. Manajemen mutu itu sendiri merupakan kegiatan terkoordinasi untuk mengarahkan dan mengendalikan organisasi dalam hal mutu (Peraturan Menteri Pekerjaan Umum ; 2009). Peran sistem manajemen mutu dalam kerangka ini antara lain seperti menentikan masukan berupa spesifikasi material yang sesuai, membuat perancanaan dan melakukan pengendalian terhadap pelaksanaan agar mencapai sasaran. Kebijakan mutu di atas ditentukan berdasarkan empat jenis kegiatan dalam manajemen mutu, antara lain:
1. Perencanaan Mutu, bagian dari manajemen yang difokuskan pada penetapan sasaran mutu dan merincikan proses operasional dan sumber daya terkait yang diperlukan untuk memenuhi sasaran mutu. Lingkup perencanaan mutu seperti pemilihan material yang tepat, pelatihan mutu dan perencanaan proses kerja. Menetapkan rencana mutu merupakan bagian dari perencanaan mutu.

2. Penjaminan mutu, bagian dari manajemen yang difokuskan pada pemberian keyakinan bahwa persyaratan mutu telah dipenuhi. Proyek pemerintah menggunakan dokumen Rencana Mutu Kontrak sebagai alat penjamin mutu yang digunakan oleh penyedia.

3. Pengendalian Mutu, bagian dari manajemen mutu difokuskan pada pemenuhan persyaratan seperti monitoring, mengurangi permasalahan dan penyimpangan yang teridentifikasi.

4. Perbaikan Mutu, bagian dari manajemen mutu difokuskan pada peningkatan kemampuan memenuhi persyaratan mutu. Persyaratan dapat dikaitakan pada aspek apapun seperti keefektifan, efisiensi atau ketertelusuran.

Penjaminan Mutu memastikan bahwa apa yang sedang dilakukan sudah benar dan dengan cara yang benar sedangkan pengendalian mutu berarti memastikan apa yang dihasilkan telah sesuai dengan harapan. Oleh karena itu, pengukuran kinerja pengendalian mutu dihitung berdasarkan seberapa besar kepatuhan pelaksaanaan pekerjaan terhadap produk penjaminan mutu antara lain penyedia jasa terhadap dokumen Rencana Mutu Kontrak (RMK) dan kepatuhan pengawas lapangan terhadap spesifikasi teknis, gambar teknis, dan dokumen administrasi terkait mutu.

Pada buletin ini akan membahas tentang kinerja pengendalian mutu dalam proyek pembangunan saluran sekunder dan lining saluran primer daerah irigasi amandit untuk pekerjaan tanah dan pekerjaan beton yang merupakan item mayor dalam pelaksanaan proyek.

Pada pekerjaan tanah pada proyek ini terbagi menjadi dua yaitu pekerjaan galian tanah dan timbunan tanah. Hal pertama yang dilakukan adalah pengajuan request sebelum pelaksanaan pekerjaan. Request diajukan kontraktor kepada konsultan pengawas dan direksi lapangan untuk mendapatkan persetujuan. Setelah diberikan persetujuan maka dilakukan check list pekerjaan terhadap gambar kerja, peralatan, material, dan tenaga kerja sudah sesuai atau belum terhadap spesifikasi teknis. Kemudian barulah dilaksanakannya pekerjaan galian tanah dan timbunan tanah tersebut.

Pada proyek ini dilakukan pekerjaan timbunan tanah terlebih dahulu, pekerjaan ini dimulai dari pemasangan bouwplank kemudian tanah diambil dari luar (quary). Excavator menggali tanah dan memuat ke dalam dump truck diangkut kurang lebih $10 \mathrm{~km}$ kelapangan material dihampar dengan menggunakan bulldozer dan grader 
perataan material timbunan $\pm 20 \mathrm{~cm}$ dan dipadatkan dengan menggunakan vibro roller sambil disiram dengan water tanker timbunan dihampar lapis perlapis (per layer) setebal $20 \mathrm{~cm}$ selama pemadatan sekelompok pekerja merapikan tepi hamparan. Seperti yang terlihat pada Gambar 1.

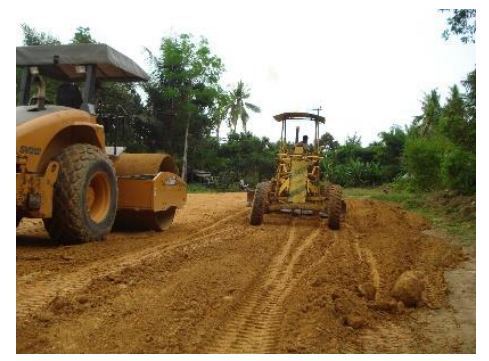

Gambar 1. Pekerjaan Timbunan Tanah,

Penghamparan Tanah, dan Pemadatan Tanah

Setelah dilakukan penimbunan tanah baru lah dilakukan pemeriksaan pemadatan tanah dengan sand cone test. Sand cone merupakan salah satu jenis pengujian yang dilakukan di lapangan, untuk menentukan berat isi kering (kepadatan tanah) asli ataupun hasil suatu pekerjaan pemaadatan, pada tanah kohesif maupun non kohesif. Percobaan ini biasanya dilakukan untuk mengevaluasi hasil pekerjaan pemadatan di lapangan yang dinyatakan dalam derajat pemadatan, yaitu perbandingan antara $\gamma_{d}$ lapangan dengan $\gamma_{d}$ maks hasil percobaan pemandatan $d i$ laboratorium dalam persentase lapangan. Sand cone terdiri dari sebuah botol plastik atau kaca dengan sebuah kerucut logam dipasang di atasnya. Botol kaca dan kerucut ini diisi dengan pasir Ottawa kering yang bergradasi buruk, yang berat isinya sudah diketahui. Di lapangan sebuah lubang kecil digali pada permukaan tanah yang telah dipadatkan. Apabila berat tanah yang telah digali dari lubang tersebut dapat ditentukan dan kadar air tanah galian juga diketahui maka berat kering dari tanah dapat diketahui juga. Setelah lubang tersebut digali (tanah asli ditimbang seluruhnya), kerucut dengan botol berisi pasir diletakkan di atas lubang itu. Pasir dibiarkan mengalir keluar dari botol mengisi seluruh lubang dan kerucut. Sesudah itu, berat dari tabung, kerucut, dan sisa pasir dalam botol ditimbang sehingga didapat volume dari tanah yang digali. Seperti yang terlihat pada Gambar 2.

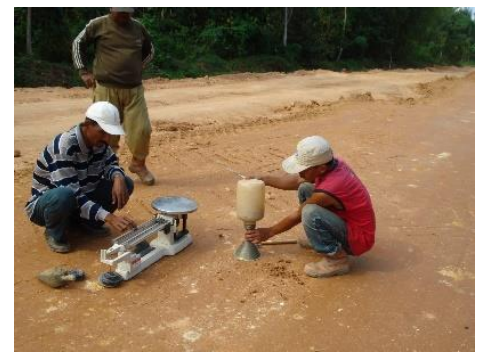

Gambar 2. Sand Cone Test
Setelah dilakukan pekerjaan timbunan tanah dan pemadatan tanah maka dilakukan pekerjaan galian tanah. Pekerjaan galian tanah dimulai dari pemasangan bouwplank. Tanah digali menggunakan alat excavator yang umumnya berada disepanjang saluran hasil galian dirapikan dengan bucket excavator. Seperti yang terlihat pada Gambar 3. Hasil galian dibuang sesuai dengan rencana tempat pembuangan. Setelah digali sesuai dengan gambar kerja dilakukan pemeriksaan hasil galian denganpengukuran untuk mendapatkan kedalaman dan kemirangan galian yang ditentukan sesuai gambar kerja.

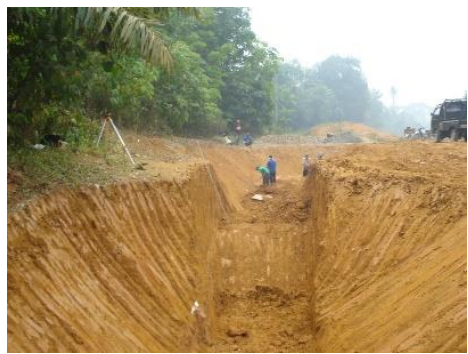

Gambar 3. Pekerjaan Galian Tanah

Seperti halnya pada pekerjaan tanah, pekerjaan beton dimulai pula dari request, kemudian di adakan checklist. Pada proyek ini pekerjaan beton dengan mutu K 175, bahan bahan yang akan digunakan semen, pasir, koral dan air dimasukkan dalam concrete mixer dan adukan dimasukkan kedalam perancah yang telah disiapkan dan dipadatkan dengan menggunakan concrete vibrator dan bahan yang digunakan harus bersih dan telah mendapat persetujuan dari konsultan pengawas dan direksi lapangan. Pada pekerjaan beton sebelumnya disiapkan job mix campuran beton yang akan digunakan pada pekerjaan tersebut dengan ketentuan mutu beton yang telah ditentukan. Pekerjaan beton setelah dilaksanakan terlihat pada Gambar 4 .

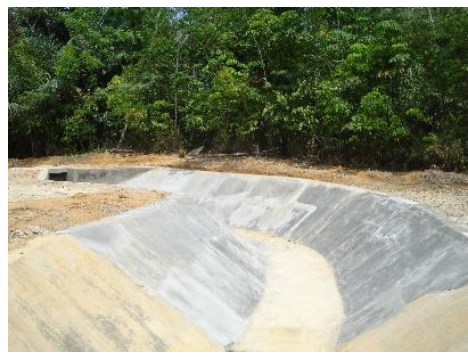

Gambar 4. Pekerjaan Beton

Pada pekerjaan beton ini dilakukan pengujian slump untuk mengetahui tingkat kemudahan pengerjaan beton yang dinyatakan dalam nilai tertentu. Slump didefinisikan sebagai besarnya penurunan ketinggian pada pusat permukaan atas beton yang diukur segera setelah cetakan uji slump diangkat. Pengujian slump dilakukan dengan menggunakan alat kerucut terpancung yang memiliki diameter lubang atas $10 \mathrm{~cm}$, diameter lubang bawah $20 \mathrm{~cm}$, tinggi $30 \mathrm{~cm}$ serta dilengkapi dengan kuping untuk mengangkat beton segar dan tongkat pemadat berdiameter $1,6 \mathrm{~cm}$ sepanjang $60 \mathrm{~cm}$. Nilai slump dipengaruhi oleh faktor air 
semen. Semakin tinggi fas maka nilai slump akan semakin tinggi yakni mengginakan banyak air dan sedikit semen, sehingga pasta semen lebih encer dan mengakibatkan nilai slump lebih tinggi. Semakin besar nilai slump test berarti adukan beton semakin mudah dikerjakan. Selain uji slump dibuat juga sampel beton untuk dilakukan uji tekan di laboratorium.

\section{Kesimpulan}

Berdasarkan rencana mutu kontrak pembangunan saluran sekunder dan lining saluran pada saluran primer daerah irigasi amandit di kabupaten hulu sungai selatan pelaksanaan terhadap pekerjaan tanah dan pekerjaan beton sudah sesuai dengan pengendalian mutu hal ini terlihat dari prosedur yang dikerjakan yang sesuai dengan spesifikasi teknis dan gambar kerja.

\section{Ucapan Terimakasih}

Dengan segala puji syukur kehadirat Allah SWT dan shalawat dan salam kepada Nabi Muhammad SAW, sehingga saya dapat menyelesaikan buletin yang berjudul RENCANA MUTU KONTRAK PEMBANGUNAN SALURAN SEKUNDER DAN LINING SALURAN PADA SALURAN PRIMER DAERAH IRIGASI AMANDIT DI KABUPATEN HULU SUNGAI SELATAN. Menyadari bahwa penyusunan buletin ini saya membutuhkan banyak bantuan dari berbagai pihak, maka saya menyampaikan ucapan terimakasih kepada:

1. Bapak Prof. Dr. Ir. Rusdi HA. M. Sc. IPU. selaku kepala program studi program profesi insinyur universitas lambung mangkurat.

2. Seluruh dosen dan karyawan program studi program profesi insinyur universitas lambung mangkurat.

3. Orang tua, saudara, suami dan anak saya atas doa dan motivasi kepada saya.

4. Teman-teman saya angkatan pertama program studi program profesi insinyur universitas lambung mangkurat.

5. Semua pihak yang membantu hingga selesainya buletin ini.

Saya menyadari kesempurnaan hanya milik Allah SWT, atas segala kekurangan dan kesalahan yang mungkin ada di dalam buletin ini saya sampaikan maaf dan terimakasih atas kritik dan saran pembaca.

\section{Referensi}

1 Mawardi, Erman. 2007. Desain Hidrolik Bangunan Irigasi. Jakata: Alfabeta.

2 Peraturan Pemerintah No. 25 tahun 2001. Tentang Sumber Daya Air. Jakarta.

3 Peraturan Menteri Pekerjaan Umum Republik Indonesia nomor : 04/PRT/M/2009 tentang Sistem Manajemen Mutu (SMM). Jakarta. 